University of the Pacific Scholarly Commons

9-1-2008

\title{
The Chilean Pension System at 25 Years: The Evolution of a Revolution
}

\author{
GregoryJ. Buchholz \\ Missouri Southern State University, buchholz-g@mssu.edu \\ Alberto Coustasse \\ University of North Texas Health Science Center, acoustas@hsc.unt.edu \\ Patricio Silva \\ Universidad Diego Portales, patricio.silva@udp.cl \\ Peter E. Hilsenrath \\ University of North Texas Health Science Center, philsenrath@pacific.edu
}

Follow this and additional works at: https://scholarlycommons.pacific.edu/esob-facarticles

Part of the Business Commons, and the Medicine and Health Sciences Commons

\section{Recommended Citation}

Buchholz, G. J., Coustasse, A., Silva, P., \& Hilsenrath, P. E. (2008). The Chilean Pension System at 25 Years: The Evolution of a Revolution. Journal of Economic Issues, 42(3), 633-647. DOI: 10.1080/00213624.2008.11507171

https://scholarlycommons.pacific.edu/esob-facarticles/68 


\title{
The Chilean Pension System at 25 Years: The Evolution of a Revolution
}

\section{Gregory J. Buchholz, Alberto Coustasse, Patricio Silva and Peter Hilsenrath}

\begin{abstract}
The 1981 reform of the Chilean pension system was revolutionary at its time. It was the first instance of a mature public Pay-As-You-Go social security system being converted into a mandatory defined contribution system managed by the private sector. This paper contends that a unique confluence of events were responsible for this change. The rise of a dictatorship in Chile, a struggling public retirement system, and a cadre of Chicago oriented economists determined to make Chile a model free market neoliberal economy. This was later followed by the Washington Consensus and the promotion of Chilean reform by the World Bank. This paper analyzes the Chilean reform and its subsequent development; evaluating it on both efficiency and equity grounds. While the evidence for efficiency gains is mixed there is little doubt that equity has suffered under the new system. Nevertheless, it continues to evolve and equity concerns are increasingly being addressed.
\end{abstract}

Keywords: Chile, Social Security Reform, Privatization, Equity and Efficiency

JEL Classification Codes: B52, D14, G23, G28, and H55

The ousting of Salvador Allende in 1973 led to a sharp reorientation of Chile's socioeconomic system. Following the coup, the country was left to cope with a moribund economy and one of the highest inflation rates in the world. Furthermore, Fischer, Sahay, and Vegh (2002), note that cumulative inflation during the 68 months between October 1971 and May 1977 was 1, 279\%. The subsequent leadership of General Augusto Pinochet and his successors championed a more free-market orientation. Economists associated with the University of Chicago were relied on to

\footnotetext{
Gregory J. Buchholz is an Assistant Professor of Finance and Economics, The Robert W. Plaster School of Business Administration, Missouri Southern State University, (417) 625-9334; buchholz-g@mssu.edu. Alberto Coustasse is a Research Assistant Professor in the Health Management and Policy Department, School of Public Health, University of North Texas Health Science Center, acoustas@hsc.unt.edu; Patricio Silva is a Professor in the School of Medicine, Universidad Diego Portales, patricio.silva@udp.cl; and Peter Hilsenrath is a Professor, Health Management and Policy Department, School of Public Health, University of North Texas Health Science Center, philsenr@hsc.unt.edu.
} 
fashion a new social order. Some would say that a cornerstone of this individualist, market-oriented approach was the social security system implemented in 1981 (Kritzer 2005). Social Security reform in Chile has drawn a great deal of attention from policy analysts in the United States (Diamond 1993; Mitchell and Ataliba 1997; Kay 2000; Ghilarducci and Ledesma 2000; Madrid 2000; Williamson 2001; Borzutzky 2003; Cypher 2004; Larraín-Ríos 2005). It has been the subject of controversy with opponents lamenting its disappointing performance while those with an interest in establishing private accounts and utilizing equities to bolster social security rates of returns have pointed to high returns and its influence upon reforms in more than twenty countries (AFP Association 2005a). It was the first conversion of a major public Pay-As-You-Go (PAYG) retirement system into a system of privately funded individual retirement accounts (Borzutzky 2003). It has been held up as the model for reform by the World Bank becoming an almost inevitable reference in any discussion about different ways to overcome the economic effects of an aging population and to reduce political risk faced by traditional social security systems around the world.

This paper will examine the 1981 reform of the Chilean social security system as well as efforts to modify the system that continued through the government of Michel Bachelet. We argue three points: First, the original 1981 reform was the result of a confluence of events. Pinochet needed an economic team to reorder the economy and made use of Chilean economists trained either at the University of Chicago or with a Chicago orientation. At the same time there was an emerging global trend for neoliberal policies that would become known as the Washington Consensus (Williamson 1993). The initial popularity of the reform was underpinned by powerful multilateral institutions promoting the Washington Consensus. The Chilean reforms became a model of what free market reforms could accomplish. To this end the World Bank has spent over $\$ 5.4$ billion promoting variants of the Chilean Social Security Reform (Hua 2006).

Our second point is that equity has been compromised by this reform. While the system continues to evolve, private individual accounts for each worker remain. Much has been written regarding social justice, much of it applicable to the question of what makes for an equitable retirement system (Rawls 1971; Ghilarducci 1992; Moss 1996; Ball and Mankiw 2001; Euzéby 2004; Nickel 2005). An equitable system should provide a minimum sufficient for subsistence for all retired citizens. It should spread risk in such a way as to protect those lacking other means of support in retirement. Income disparities during retirement years should not be worse than those during working years. It should be more than a retirement savings vehicle and should include aspects of social insurance such as disability and survivors benefits. Finally, it should be financed on an ability to pay basis. Many workers avoid contributing to the new system and therefore will receive little in the way of retirement benefits from it. This wide scale non-participation indicates the lack of support enjoyed by the system and points to perceptions that it may not be equitable. The fact that one of the major planks of President Bachelet's campaign was reform of the system further indicates concern about equity.

Our third argument is that one of the goals of the reform, to promote efficiency, has been at best, only partially achieved. An efficient social security system should be 
universal in order to foster widespread support and generate economies of scale and scope. Administration of the system should absorb a small percentage of workers' contributions. Returns should be comparable to those elsewhere within the country for given levels of risk. If possible, it should not distort either capital or labor markets. High administrative costs have reduced benefits that participants expect from the system and finally, portfolio constraints, designed to reduce workers' exposure to risk have effectively reduced the risk-adjusted rate of return that the new accounts are able to produce. It is not clear that pension reforms have improved efficiency but it is clear that concerns about equity remain.

While there is evidence that capital markets have developed (Morande 1998; Corbo and Schmidt-Hebbel 2003) the small size of the Chilean market results in too few private domestic outlets for social security funds. Increasingly the retirement industry has become concentrated in the hands of six firms and this lack of competition has resulted in higher than necessary administrative costs and large profits (Diamond and Valdés-Prieto 1994).

Participation by the self-employed is voluntary. Therefore, they can either opt out of the system or participate but not fully declare their income. Survivors also have rights to benefits earned by a spouse or parent. Nevertheless, this aspect of social insurance accrues only to participants in the system and we will explain that a significant portion of the Chilean workforce either completely avoid participation or participate only sporadically.

Institutional economics is uniquely suited to examining the evolution of the Chilean Social Security System. The "old" school of institutional economics has been defined as having five key characteristics: 1) it is not defined by any policy proposals; 2) it is interdisciplinary relying heavily on fields such as psychology, sociology, history and anthropology to better understand human behavior; 3) institutions are emphasized for their importance and special attention is placed on innovation and technical change; 4 ) it is recognized that institutions are embedded in a broader set of social, cultural, political and power relationships; and 5) the traditional neoclassical utility maximizing model of individual behavior is considered inadequate because it does not satisfactorily account for social, cultural and other influences (Hodgson 2000). This fifth point is probably the most important differentiating factor between the old and new schools. But it is the fourth point that is of greater relevance here. The importance of social influence and cultural norms on conformity has long been emphasized as critical to understanding a wide range of economic activities and Chile's experience should be seen in such a context (Commons 1931; Mitchell 1910).

\section{The Chilean Social Security Program and its Reform}

Pinochet took power at a time when a cadre of Chicago oriented economists were positioned to assume policy making roles in the government. These economists shared the same liberal thinking as Milton Friedman and Arnold Harberger and implemented the new pension system with the backing of Pinochet (Barber 1995; Silva 2004). At the time the reform was introduced the Washington Consensus was 
not a fully articulated policy prescription but the Reagan administration was clearly signaling its preference for business over labor and markets over government. Multilateral lending institutions were also searching for mechanisms by which markets and free trade could be encouraged.

Prior to its reform, the Chilean system, which was created in 1925, was a very comprehensive social security program that covered more than 70 percent of the population (Borzutzky 2003). Nevertheless, the system faced financial stress with high costs and expenditures reaching 17 percent of GNP in 1971 (Teissonniere 2005). Benefits were unequal as were contributions. There were 100 different pension schemes run by 32 institutions, each with its own financial arrangements (Altman 2004). In some cases, payroll taxes were as high as 69 percent of wages (Acuña and Iglesias 2001). Each time a new group of workers was given coverage it was subject to different rules with different benefits. Also, affiliation to each institution was tied to the economic sector in which the worker was employed and the lack of competition reduced incentives for efficiency (Cheyre 1991). Beginning in the 1950s, succeeding presidents tried to reform the system with little luck. Everybody wanted to change the system as long as such change did not harm their interests (Borzutzky 2003).

Pinochet was determined to alter political relations of the Chilean state (Silva 1993; Loveman and Davis 1997; Borzutzky 2003). The old pension system encouraged political organization by interested stakeholders. Groups that gained from different tax and benefit structures fought to defend them. The new model, by instituting a system of private accounts, effectively atomized participants. Each individual was interested only in the performance of his or her account. In addition Pinochet banned all union activity.

Infused with free-market idealism, the Chilean government declared that their retirement scheme would be a model of free-market provision of a governmentally mandated Social Security system. José Piñera, then Minister of Labor and Social Welfare, began working on the existing hodge-podge of industry-based social insurance plans. The plan was drafted by a commission, headed by economist Martin Cóstabal but Piñera was the intellectual author of the reform. The commission worked in secret and consulted with none of the social groups present in civil society. It totally transformed the administrative, financial, and benefits structures of the social security system. It should be noted that this plan, implemented by the military dictatorship, did not include the armed forces. Their system remained untouched (Borzutzky 2003).

The World Bank began to publicly promote Chilean style systems. Their public justification for supporting pension reform has been that public pension systems do not deliver on their social objectives; they have created severe distortions in the operation of market economies and are not financially sustainable when facing aging populations (Palacios 2004). A transition from defined benefit to defined contribution plans was seen as fiscally responsible. More than 20 countries on four continents have adopted the defined contribution approach to social security. 
Table 1: Reforms Based on Saving and Individual Accounts

\begin{tabular}{cl}
\hline \hline Year & \multicolumn{1}{c}{ Countries } \\
\hline 1981 & Chile \\
1993 & Peru \\
1994 & Argentina, Colombia \\
1995 & Uruguay \\
1997 & Mexico, Bolivia, Panama \\
1998 & El Salvador, Hungary, Kazakistan \\
1999 & Poland \\
2000 & Costa Rica \\
2001 & Latvia \\
2002 & Bulgaria, Croatia, Estonia, Kosovo \\
2003 & Dominican Republic, Russian Federation, India \\
2005 & Slovakia, Nigeria, Nicaragua, Ukraine, Lithuania \\
\hline In the process of & Macedonia \\
implementation & \\
& \\
\hline \hline
\end{tabular}

Source: (AFP Association 2005a).

Two benefits were expected from the Chilean reform. First, by reducing social security contributions, which averaged twenty-five percent of payroll, to ten percent, incentives to work should have increased. Second, by allowing contributions to be invested in private securities it was thought that capital markets would be deepened and broadened (Mitchell and Flavio1997; Corbo and Schmidt-Hebbel 2003). Stephen Kay (1999), however, notes that transition costs, which consist of the government's accrued liabilities to workers enrolled in the old system at the time of the reform, were nearly five percent of GDP and this was confirmed by a Chilean government report which found that the new system generated fiscal deficits averaging 5.7 percent of GDP in the period 1981-1998 (MIDEPLAN 2000). More recent data shows that the total fiscal deficit due to spending on retirement income peaked at 7.6 percent in 1984 but had fallen to six percent by 2002 (Arenas de Mesa 2004). Increased flows to capital markets were thus to a large degree offset by these deficits.

\section{The 1981 Reform}

The core of the system is a mandatory 10 percent contribution every employee must make to a defined contribution plan each month. These plans are managed by Pension Fund Administrators (Administradoras de Fondos de Pensiones [AFPs]), private firms whose sole function is to administer individual retirement accounts and to provide social security benefits. The AFP is a for-profit corporation and profits 
result from the commissions charged for the administration of the retirement accounts (AFP Association 2006a; Borzutzky 2003; Berstein and Chumacero 2005). There is an additional contribution of two percent of wages charged as a monthly premium for term life and disability insurance and both of these contributions are subject to a maximum wage base. Finally, the commission fees charged by each AFP have ranged from 0.6 percent to one percent of wages per month (Edwards 1996). The AFPs, in turn, provide insurance against old-age as well as disability and survivor's benefits for a member's widow, widower if disabled, the mother of a member's illegitimate child or the deceased member's offspring. Members may retire upon reaching the legal retirement age of 65 (60 if they are women) or 10 years short of the legal retirement age if they have accumulated funds sufficient to pay a pension of at least 50 percent of their average taxable income for the previous 10 years (SAFP 2006a).

The AFPs are overseen by the Superintendencia de Administradoras de Fondos de Pensiones (SAFP) (Office of Pension Fund Administrators Supervision), which is the controlling organization that represents the State within the Chilean system of pensions based on individual capitalization. It is an autonomous entity, which is financed with funds from the public budget, whose highest authority is the Superintendent, named by the President of the Republic and which coordinates with the government through the Ministry of Labor and Social Welfare (Acuña and Iglesias 2001; SAFP 2006a; 2006b; 2006c). The SAFP began its oversight functions on May 1, 1981 and this supervisory, technical and highly professionalized organization has as its objective the supervision and control of the AFPs and of the Administradora de Fondos de Cesantia (AFC) (Unemployment Fund Administrator). These entities, which collect the contributions, invest the resources and pay the retirement and unemployment benefits to those insured (SAFP 2006b). The SAFP should not be confused with the trade and lobby organization for the AFPs, which is the Chilean Pension Fund Administrators' Association, which began its operation on October 14, 1981, just five months after the 1981 reform (AFP Association 2006a). This organization provides statistical data and studies to promote Chilean style systems around the world.

Since its reform the Chilean pension system has undergone two more changes both occurring during the post-1991 democratic government era. The first, in 2002, was the introduction of five different fund types, called multi funds, in which members could invest (Larraín-Ríos 2005). These are similar to what participants use in defined contribution plans in the United States. The key difference is that members may only choose one fund type to house their contributions. In general, anyone belonging to the system may choose one of five funds, with the exception of men over the age of 55 and women over the age of 50 who are not pensioners (SAFP 2006c). They may opt for only four of the five funds. They may not invest in Fund A, which has most of its investment portfolio in equities. In the same way, pensioners using programmed withdrawal can only choose between the three funds with lower investment in equities (Funds C, D and E). The restrictions referred to above are only applicable to savings in the Mandatory Individual Capitalization Account. Members 
may change funds up to twice a year without cost and funds belonging to the same AFP have identical commissions. The structure of funds is shown in Table 2 below and includes different risk and investment tools including hedging operations (SAFP 2006c).

Table 2 shows the portions of a fund's portfolio that can be held in the two main types of assets. Fund $E$ is the most conservative and is suitable for those close to retirement. Fund D contains a bit more risk and is the default fund that men older than 55 and women older than 50 are assigned to if they fail to make a choice. Fund $\mathrm{C}$ is the default for those men aged 35 to 55 and women aged 35 to 50 while men under 35 and women under 35 are assigned to fund B. The riskiest portfolios are those held in Fund A. This choice of funds allows workers to tailor their portfolios to their level of risk aversion and their life-cycle stage (SAFP 2006c).

\section{Table 2: Maximum and Minimum Investments by Fund Type in the Chilean AFP System}

\begin{tabular}{lccccc}
\hline \hline & \multicolumn{5}{c}{ Fund Type } \\
\hline Investment Type & $\mathrm{A}$ & $\mathrm{B}$ & $\mathrm{C}$ & $\mathrm{D}$ & $\mathrm{E}$ \\
\hline Minimum fixed return assets & $20 \%$ & $40 \%$ & $60 \%$ & $80 \%$ & $100 \%$ \\
Maximum variable return assets & $80 \%$ & $60 \%$ & $40 \%$ & $20 \%$ & None \\
Minimum variable return assets & $40 \%$ & $25 \%$ & $15 \%$ & $5 \%$ & None \\
\hline \hline
\end{tabular}

Source: SAFP 2006b: 16.

The other change by the democratic government was the introduction in 2003 of a voluntary retirement savings program. In this program the worker has the choice of depositing amounts above the mandatory 10 percent into an AFP. These funds are tax-deferred and workers can deposit up to about US $\$ 1,750$ per month (AFP Association 2006b; 2006c). These provide additional protection to medium to high income workers who can afford to save (World Bank 1994).

\section{Evaluation of the Reform}

Two important questions about the reform must be answered. Was it equitable and was it efficient? We answer in the negative to equity and find an ambiguous impact on efficiency. President Bachelet improved the equity of the system but these reforms have so far fallen short of what is necessary. Further, far too many people, it is projected, will qualify for only a minimum pension after a lifetime of labor (Hua 2006, 1). As for efficiency, the evidence is mixed in terms of capital market 
improvements and there is evidence that labor markets may be distorted by the reform (Packard 2007).

As previously noted, an equitable system should provide a minimum sufficient for the subsistence of all retired citizens. One of the worker protections provided by the Chilean system is a guaranteed minimum benefit for those retiring with ten years of credits but insufficient assets in their portfolios to provide such a benefit (Diamond 1993; AFP Association 2004). The minimum benefit scheme was introduced at the time of the 1981 reform but has been found to be inadequate. President Bachelet campaigned on a platform that called for reform of the Social Security system. In her first month in office she raised the minimum pension, received by 1.2 million persons, by 10 percent; 90 percent of this increase went to those in the old system and 10 percent to participants in the AFP system. This new improvement in the Chilean pension system will cost around US $\$ 180$ million and will be financed by maintaining Chile's value-added tax at 19 percent instead of reducing it to 18 percent as had been mandated by law (La Tercera 2005).

Risk should be spread in such a way as to protect those most vulnerable. Retirement income can come from a mixture of three sources: social security, private saving and employer provided pensions. Low income workers typically do not have the means to save on their own. Nor are they often provided with pensions by their employers. This means that their primary source of income during retirement years comes from social security. However, Chile's social security transformation has subjected savers to macroeconomic fluctuations.

All wage based social security programs will be subject to the risk that unemployment brings with it, the interruption of employment and hence contributions. The difference between a mandatory savings plan (defined contribution) and a formula based plan (defined benefit) is that the size of the benefit in a defined contribution plan is also a function of how well the portfolio performs. A defined contribution plan only works if one contributes to it. A major criticism of the Chilean program is that most informal sector workers do not belong to an AFP and that many of those workers, formal and informal, who are affiliated with an AFP, fail to make contributions. The fact that about 36 percent of the Chilean workforce belongs to the informal sector has led to estimates that as many as 50 percent of eligible workers may not be contributing to the system (AFP Association 2006b; 2005b). The graph below, developed from data taken from the AFP Association's web page shows that contribution rates of members have been falling over time. In 2005, only 49 percent of members were making contributions, a figure which has fallen since 1985 (authors' calculations from AFP Association 2006b). Nevertheless, the association boasts that 66 percent of those in the workforce are covered (AFP Association 2005b).

Our own analysis of the Chilean Survey of Socioeconomic Status [Encuesta de Caracterización Socioeconómica] (CASEN) 2003 data, showed that 26.5 percent of respondents belonged and contributed to an AFP while another 21.2 percent belonged but did not contribute (Buchholz, Coustasse and Silva 2006). 
Figure 1. Contribution to an AFP as a Percent of AFP Members

Percent of AFP Members That Contribute

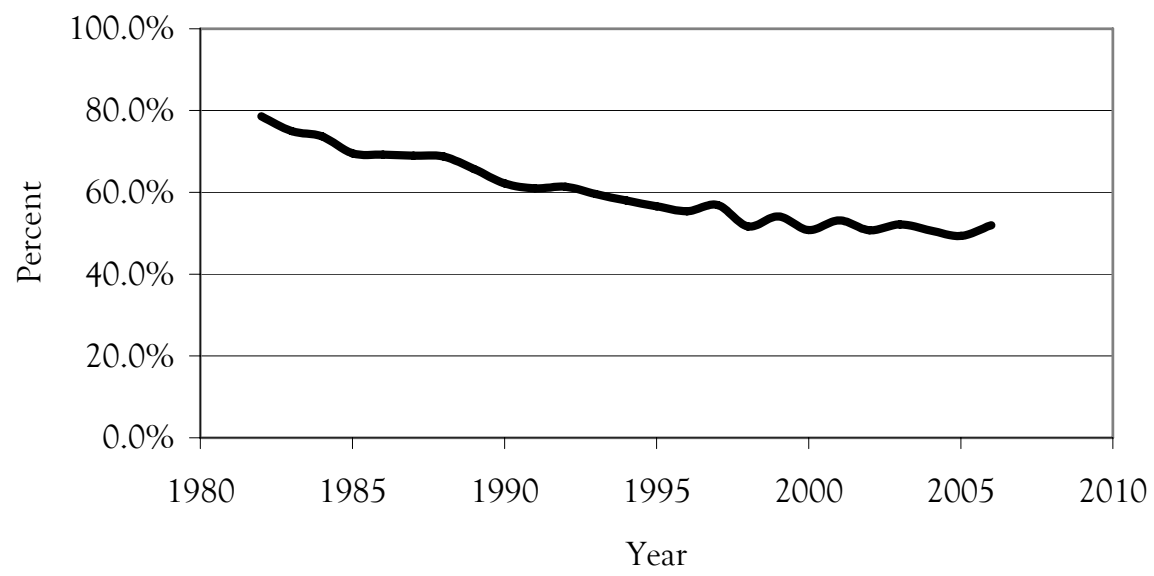

Source: Authors' calculations from AFP Association 2006b.

Several problems flow from this. One is that the amount accumulated by the worker in his or her AFP will be undermined for each month a contribution is not made. This will increase the number of retirees eligible for the minimum pension which is, at this time, insufficient to provide even a subsistence income. Substantial differences of opinion exist on what kind of income distribution is equitable and fair. Institutional economics stands out here in an important and related way. Institutional economists, especially of the old school, commonly believe that an important attribute of an economic system is the provision of a decent standard of living (Gordon 1980). Many countries of the world generate a sufficient level of output to provide such a minimum level of economic welfare for their populations. Social security systems are meant to provide acceptable minimums for retirees and others who cannot work. If a social security system evolves into a pension system with returns dependent on portfolio performance the security in the system is jeopardized. The ability to provide a basic minimum, in spite of asset allocation controls, has been undercut and those who sustain market losses, or even insufficient gains, will suffer. Chile's public pension system does provide minimum benefit levels and in December 2006 these ranged for adults from approximately US\$663 per year to US\$2,374 per year using market exchange rates (Instituto Nacional de Pensiones (INP) 2006). The range is a function of age, health status and the existence of dependents. These levels of support understate living conditions and a better measure relies on the World Bank's purchasing power parity index. This yields a range from US\$1,293 to US\$4,629 in a country with a purchasing power parity adjusted per capita income of $\$ 11,470$ in 2005 (World Bank 2006). 
Further, one of the basic principles of social insurance is broad coverage of the population in order to spread risk. While it is true that the Chilean Social Security system provides disability and survivor's benefits, they are predicated upon participation. The high level of noncompliance with the system has produced large holes in the safety net. We see adverse selection at play here in which those most in need of risk protection opt out of the program. That they are able to do so is the result of flaws in the design of the program.

An equitable system also would be financed on an ability to pay basis. It is tempting to say that this is met because all participants contribute a flat $10 \%$ of their salaries to an AFP and therefore the system uses proportional financing. While many argue that progressive financing is better, most contend that proportional financing meets the bare minimum of an equitable system. But there is a problem with the minimum pension. The majority of those who receive this are low-income retirees. However, it is possible to participate in the system in a high paying job for nine years, leave it by way of self-employment, and then return in the last year before retirement in order to accumulate the ten years necessary for the minimum benefit. Current rules require that a worker contribute during the final year of employment. Part of the minimum, which comes out of general revenue, will therefore be paid to upper income workers resulting in a transfer from poor to rich.

Finally the goal of promoting efficiency has only been partially achieved. The system should absorb a small percentage of workers' contributions in terms of administrative costs. We have already seen that when calculated on the basis of percent of contribution that these costs range from six percent to ten percent (Diamond and Valdés-Prieto 1994). This compares with the U.S. Social Security system which absorbs less than one percent.

Buoyed by high and falling interest rates, the AFPs delivered a 10.5 percent real average yield from its inception (Andrews 2006). Nevertheless this return may be more than meets the eye. Diamond observed that during the period from 1981 to 1993 the Chilean economy generated high rates of return in general and that fund managers could not be credited with particularly astute investment choices (Diamond 1993). Yet they certainly have been expensive. Between 1981 and 1998 unadjusted returns were 11 percent. When administrative expenses are deducted this falls to an estimated 5.1 percent (Kay 1999).

One way to compare this is to look at various market indices. The Morgan Stanley Emerging Markets Equity Portfolio began in 1992 and has averaged 12.6\% and its Emerging Markets Debt Portfolio has averaged $11.1 \%$ since its inception in 1994 (Morgan Stanley 2007). The Standard \& Poor's (S\&P) Latin America 40 index has averaged $18.7 \%$ over the past ten years while the S\&P 500 has averaged $6.7 \%$ over the same period (Standard \& Poor 2007).

A recent record of inadequate returns was admitted by the Superintendent of AFPs in 2005, when it released a study showing an estimated loss of close to $\$ 6$ billion, equivalent to a tax of more than five percent of the investments of the affiliates since the inception of the AFP system due to the restrictions placed on acceptable AFP investment vehicles and restrictions on the amount that could be 
invested outside of Chile, which is 30 percent (Berstein and Chumacero 2005). The Office of AFP Supervision recognized as well that without such regulation, affiliates would have been exposed to greater risk (Berstein and Chumacero 2005). It was in response to such criticisms that the multi fund system was created.

Proponents of pension finance reform in Chile argue that privatization has improved the efficiency of capital markets and resulted in higher levels of productivity and faster economic growth. They also contend that savings rates have increased. Chile has indeed grown faster than other Latin American countries. The World Bank reports Chile's average annual growth from 2000 to 2004 at 3.4 percent. This exceeds that of Argentina ( -0.1 percent), Brazil (2.0 percent) and Uruguay ( -1.2 percent) (World Bank 2006). But there are many factors that drive growth and it is often difficult to determine the importance of a single factor, such as capital markets from the aggregate data. The econometric work that has been done shows with a fairly high degree of confidence that Chile's capital markets have become more efficient and have contributed to faster economic growth (Morande 1998; Kassimatis and Spyrou 2001). The question remains however, whether this can be attributed to social security reform which was, after all, only one piece of a widespread systemic reorientation.

\section{Discussion}

The Chilean pension system as it enters its twenty-sixth year remains in need of further adjustments or corrections. As a provider of retirement income to those currently retired it appears to have done an adequate job for some. Yet a large percentage of pensioners are drawing the minimum pension guaranteed by the state indicating that their accounts are not sufficient to provide the higher pensions promised by the reform. It should also be noted that the period 1981-2004 saw higher rates of return than can be expected in the future. Further, gaps in contributions produced by spells of unemployment or noncompliance will put downward pressure on accumulations and hence benefits (Soto 2005). On the brighter side, many expect administrative fees to fall as the system matures. It should be noted, though, that much younger systems than Chile's already have lower administrative expenses. Mexico and Uruguay both have lower expenses. Peru and Argentina have equal levels of expense (Mitchell 1999). The much older U.S. system which remains PAYG has expenses 50 percent less than any other country mentioned above (Diamond 1993).

Chile's economic reforms and the enthusiasm that many hold for them should be viewed in light of conservative values and perspectives that solidified in the 1980s and 1990s. Global stagflation in the 1970s led to disillusion with Keynesian demand management and a shift toward more supply side orientations. Many favored greater market rigor to boost productivity and output. In economic development circles the "Washington Consensus" evolved calling for economic "liberalization" with limited roles for government, generally confined to protecting private property, education and health (Williamson 1993; Gualerzi 2005). This ethic became the norm in financial circles and to a lesser extent among academics. 
Important and powerful players buttressed these conventions. Multilateral organizations such as the International Monetary Fund, the World Bank, and the United Nations along with proprietary financial ties formed a backdrop of power relations and attitudes that helped underpin the legitimacy of Chile's experience. The transmission of values in support of institutions that serve elites is a familiar and consistent theme in institutional economics from Veblen to the present (Veblen 1953). Yet for most communities of economists and other social scientists these important issues are often ignored or downplayed (McConnell 1970).

Chile's relatively high growth rates have been touted as evidence of the success of the Pinochet approach to social security, in spite of ambiguous theoretical and empirical findings that national savings rates were increased as a result of privatization of retirement accounts (Congressional Budget Office (CBO) 1999; White 2000). The primary impact of privatization of social security funds on macroeconomic finance is simply to change the identity of those who hold government debt (Eisner 1998). Any real change in structure requires alterations in the supply of equity and debt. It is difficult to determine if changes in public savings in Chile offset increases in private savings. The privatization of retirement accounts in Chile has had other effects that are more clearly positive. There does seem to be agreement that capital markets developed more than would otherwise have occurred and this may have stimulated economic growth (Arenas de Mesa and Mesa-Lago 2006). However, social security reform occurred in the context of other growth measures such as trade liberalization. Equity, or distributive justice is perhaps of greater concern and it has been given short shrift in many assessments of Chile because equity has not been a pressing priority under the Washington Consensus. It is often asserted that a rising economic tide will eventually lift all boats.

A major problem facing Chile's system is lack of participation. If a solution to this dilemma is not found, the Chilean state will be facing the prospect of paying minimum pensions to a majority of retirees. Elimination of the option to opt out by the self-employed would be one step toward solving this problem. Another might be for the state to match part of the workers' contributions up to some maximum in much the same way as U.S. 401(k) plans include employer matches. Also, tax incentives could be given to firms in the formal sector to sponsor pension plans that would supplement social security and serve to draw workers from the informal sector.

Praise for Chile's pension system transcends its national institutions. The same arguments have been used to urge analogous social security reforms in the United States including those put forward by President George W. Bush. But Chile's reforms do not assure gains in efficiency for the United States. U.S. financial markets are already well developed and there is no guarantee that national savings rates will rise. A greater return for social security recipients is a laudable objective but the risks associated with privatization are unacceptable unless a decent minimum level of support can be assured. The U.S. social security system may need reform, but fiscal problems, yet to arise, should not be used to undermine one of the most important pillars of social stability established in the $20^{\text {th }}$ century (Papadimitriou and Wray 1999; Bell and Wray 2000; Buchholz 2007). 
Finally, it should be remembered that social security systems are nothing more than financing mechanisms. The standard of living of retirees will depend on the productivity of their children and grandchildren. Once one ceases to produce, his or her consumption must come out of the production of those who are younger. Pension schemes have a tremendous impact upon the distribution of consumption, but more important to the retirement income of much of the population is the continuing health of that economy during their working and retirement years.

\section{References}

AFP Association. "The AFP System: Myths and Realities." Research Department, 2004. http://www.afpag.cl. (Accessed May 2006).

"24 Years On, Chile Still Leads the Way in Social Security Reforms." AFP Association Research Series No. 48, 2005a. http://www.afp-ag.cl. (Accessed June 2006).

—. "La Realidad Provisional de las Regiones." Serie de Estudios, Nº 49, May, 2005b. http://www.afpag.cl. (Accessed April 2006).

—. "Who we are." Asociación AFP, June 4, 2006a. www.afp-ag.cl, (Accessed December 2006)

- "Changes in the Numbers of Members," and "Changes in the Numbers of Contributors." AFP 2006b. http://www.afp-ag.cl/ (Accessed February 2007).

—. "Ahorro provisional Voluntario APV." AFP 2006c. http://www.afp-ag.cl/ppt/apv.ppt. (Accessed February 2007).

Acuña, Rodrigo and Augusto Iglesias. Chile's Pension Reform After 20 Years. Social Protection Discussion Papers Series, no. 129, World Bank, December 2001. http://siteresources.worldbank.org/ SOCIALPROTECTION/Resources/SP-Discussion-papers/Pensions-DP/0129.pdf (Accessed June 2008).

Altman, Daniel. "Uneven Benefits." Business 2.0. August 2004.

Andrews, Emily, Pension Reform and the Development of Pension Systems: An Evaluation of World Bank Assistance. Washington, D.C.: The World Bank, 2006.

Arenas de Mesa, Alberto. "Política fiscal y garantías explícitas del sistema de pensiones en Chile." Santiago de Chile: Cepal, Naciones Unidas, January 26-28, 2004.

Arenas de Mesa, Alberto and Carmelo Mesa-Lago. "The Structural Pension Reform in Chile: Effects, Comparisons with Other Latin American Reforms, and Lessons." Oxford Review of Economic Policy 22, 1 (2006): 149-167.

Ball, Laurence and N. Gregory Mankiw. "Intergenerational Risk Sharing in the Spirit of Arrow, Debreu, and Rawls with Applications to Social Security Design." National Bureau of Economic Research Working Paper Series, Working Paper 8720. May 2001. http://www.nber.org/papers/w8720 (Accessed December 2003).

Barber, William J. “Chile con Chicago: A Review Essay." Journal of Economic Literature 33, 4 (December 1995): 1941-1949.

Bell, Stephanie and Wray, L. Randall. "Financial Aspects of the Social Security 'Problem'." Journal of Economic Issues 34, 2 (2000): 357-364.

Berstein, Solange and Rómulo Chumacero. "Cuantificación de los Costos de los Límites de Inversión para los Fondos de Pensiones Chilenos.”. Santiago: Series de Documentos de Trabajo. Superintendencia de Administradoras de Fondos de Pensiones, April 2005.

Borzutzky, Silvia. "Social security privatizations: the lessons from the Chilean experience for other Latin American countries and the USA." International Journal of Social Welfare 12, 2 (2003): 86-96.

Buchholz, Gregory. "Chilean Social Security Reform: Applications for the US Social Security Debate." Southern Business and Economic Review 26, 2 (2007): 3-7.

Buchholz, Gregory, Alberto Coustasse and Patricio Silva. "How well does the Chilean AFP system serve retirees?" Paper presented at the XXVI International Congress of the Latin American Association (LASA), San Juan, PR, 2006.

Congressional Budget Office (CBO). "Social Security Privatization: Experiences Abroad." Washington, D.C., 1999. 
Cheyre, Hernán. La Prevision en Chile Ayer y Hoy. Second Edition. Santiago: Centro de Estudios Públicos, 1991.

Commons, John R. "Institutional Economics." American Economic Review 21, 4 (1931): 648-657.

Corbo, Vittorio and Klaus Schmidt-Hebbel. "Effects macroecónomicos De La Reforma De Pensiones En Chile.” 2003. http://www.josepinera.com/text/corbo-schmidt.pdf (accessed May 2006).

Cypher, James M. "Pinochet meets Polyani? The Curious Case of the Chilean Embrace of 'Free Market Economics'." Journal of Economic Issues 39, 2 (2004): 527-535.

Diamond, Peter. "Privatization of Social Security: Lessons from Chile." Working Paper No. 4510. National Bureau of Economic Research Working Paper Series, 1993.

Diamond, Peter and Salvador Valdés-Prieto. Social Security Reforms. In The Chilean Economy: Policy Lessons and Challenges, edited by B. Bosworth, R. Dornbush and R. Labán, pp. 257-328. Washington, D.C.: The Brookings Institution, 1994.

Edwards, Sebastián. "The Chilean Pension Reform: A Pioneer Program” Working Paper 5811. National Bureau of Economic Research. Working Paper Series, 1996.

Eisner, Robert. "Save Social Security From its Saviors." Journal of Post Keynesian Economics 21, 1 (1998): 963 968.

Euzéby, Alain. "Social protection: Values to be defended!" International Social Security Review 57, 2 (2004): 107-117.

Fischer, Stanley, Ratma Sahay, and Carlos A. Vegh. "Modern Hyper- and High Inflations." IMF Working Paper No. 02/197. November 2002. Available at SSRN: http://ssrn.com/abstract $=880323$. (Accessed April 2003).

Ghilarducci, Teresa. Labor's Capital. Cambridge, MA: The MIT Press, 1992.

Ghilarducci, Teresa and Patricia Ledesma. "Union's Role in Argentine and Chilean Pension Reform." World Development 28, 4 (2000): 753-762.

Gordon, Wendell. Institutional Economics. Austin: University of Texas Press, 1980.

Gualerzi, Davide. "Stiglitz on Globalization and Development with an Eye to Keynes." Review of Political Economy 17, 2 (2005): 317-329.

Hodgson, Geoffrey. "What is the Essence of Institutional Economics?" Journal of Economic Issues 34, 2 (2000): 317-329.

Hua, Thao. World Bank Pension Policy Misses Mark: Internal Report Finds Bank Relied Too Much on Chilean Model's Capital Markets Development. Pension and Investments, March 6, 2006.

Instituto Nacional de Pensiones (INP). Montos de pensiones mínimas y asistenciales. http://www.inp.cl/ portal/pensionados/montos.html. (Accessed September 27, 2007).

Kassimatis, Konstantinos and Spyros Spyrou. "Stock and Credit Market Expansion and Economic Development of Emerging Markets: Further Evidence Using Cointegration Analysis." Applied Economics 33, 8 (2001): 1057-1064.

Kay, Stephen J. "Unexpected Privatizations: Politics and Social Security Reform in the Southern Cone." Comparative Politics 31, 4 (1999): 403-422.

__. "Review: Privatizing Pensions: Prospects for the Latin American Reforms." Journal of Interamerican Studies and World Affairs 42, 1 (2000): 133-143.

Kritzer, Barbara. "Individual Accounts in Other Countries." Social Security Bulletin 66, 1 (2005): 31-37.

$\mathrm{La}$ Tercera. Bachelet propone cambios tributarios para financiar reformas al sistema de pensiones. October 19, 2005.

Larrain-Ríos, Guillermo. "Enhancing the Success of the Chilean Pension System: The Addition of Multiple Funds and Annuities." In A Quarter Century of Pension Reform in Latin America and the Caribbean: Lessons Learned and Next Steps, edited by Carolin A. Crabbe, pp. 219-240. Washington, D.C.: InterAmerican Development Bank, 2005.

Loveman, Brian and Thomas M. Davis, Jr. The Politics of Antipolitics: The Military in Latin America. Wilmington, DE: Scholarly Resources, 1997.

Madrid, Raúl. "Understanding the Wave of Pension Reforms." International Social Security Journal 163 (2000): 51-59.

McConnell, Grant. Private Power and American Democracy. New York: Vintage Books, 1970.

MIDEPLAN. El Sistema de Pensiones Administrado por el Sector Privado en Chile: Un Análisis Institucional. Santiago de Chile: Ministerio de Planificación y Cooperación, 2000. 
Mitchell, Olivia S. "Evaluationg Administrative Costs in Mexico’s AFORES Pension System.” Pension Research Council. University of Pennsylvania. January 1999. http:/ www.pensionresearchcouncil.org/publications/document.php?file=59 (Accessed July 13, 2007).

Mitchell, Olivia S. and Flavio, Ataliba. "After Chile, What? Second-Round Pension Reforms in Latin America.” Working Paper No. 6316, National Bureau of Economic Research Working paper Series, 1997.

Mitchell, Wesley C. “The Rationality of Economic Activity Part II.” Journal of Political Economy 18, 3 (1910): $107-216$

Morande, Felipe. “Savings in Chile. What Went Right?” Journal of Development Economics 57, 1 (1998): $201-$ 228.

Morgan Stanley. "Morgan Stanley Institutional Funds” http://www.morganstanley.com/im/performance/ index.html?page=prod (Accessed September 27, 2007).

Moss, David A. Socializing Security: Progressive-era Economists and the Origins of American Social Policy. Cambridge, MA: Harvard University Press, 1996.

Nickel, James W. "Poverty and Rights.” The Philosophical Quarterly 55, 220 (July 2005): 385-402.

Packard, Truman G. Do Workers in Chile Choose Informal Employment? A Dynamic Analysis of Sector Choice. World Bank Policy Research Working Paper 4232. Washington, D.C.: The World Bank, 2007.

Palacios, Robert. Pension Reform in Latin America: Design and Experiences. Washington, D.C. Work Bank. (2004). http://www-wds.worldbank.org/external/default/WDSContentServer/IW3P/ IB/2007/05/04/000016406 20070504135015/Rendered/PDF/wps4232.pdf. (Accessed July 16, 2007).

Papadimitriou, Dimitri B. and Wray, L. Randall. “Does Social Security Need Saving?” Public Policy Brief No. 55. The Jerome Levy Institute of Bard College, 1999.

Rawls, John. A Theory of Justice. Cambridge, MA: Harvard University Press, 1971.

Silva, Eduardo. "Capitalist Coalitions, the State, and Neoliberal Economic Structuring: Chile 1973-88." World Politics 45, 4 (1993): 526-559.

Silva, Patricio. "Doing Politics in a Depoliticised Society: Social Change and Political Deactivation in Chile." Bulletin of Latin American Research 23, 1 (2004): 63-78.

Soto, Mauricio. "Chilean Pension Reform: The Good, the Bad and the in Between” An Issue in Brief, Center for Retirement at Boston College, 31 (2005).

SAFP. Superintendencia de Administradoras de Fondos de Pensiones, "Pensiones." SAFP 2006a. http:// www.safp.cl/sist previsional/index.html, (Accessed April 4, 2007).

"Preguntas Frecuentes Sobre El Sistema Previsional Chileno y el Seguro de Cesantía: Información del sistema para el afiliado y cotizante." SAFP 2006b. http://www.safp.cl/inf_afiliados/pf/pf2.html. (Accessed April 7, 2007).

—_. "Preguntas Frecuentes Sobre El Sistema Previsional Chileno y el Seguro de Cesantía: Multifondos." http://www.safp.cl/preg_frecuentes/index.html. SAFP 2006c. (Accessed April 7, 2007).

Standard \& Poor. "Standard \& Poor's Reports August Index Returns." 2007.

http://www2.standardandpoors.com/spf/pdf/index/tr_new.pdf (Accessed September 27, 2007

Teissonniere, Georgianne. "Lessons From Around the World: International Pension Programs offer Valuable Lessons for Social Security Reform Proposals.” Caribbean Business February 24, 2005.

Veblen, Thorstein. Theory of the Leisure Class. New York: Mentor Books, 1953.

White, Joseph. "Looking in the Wrong Place: Why Chile Provides No Evidence for Social Security Privatization.” Public Budgeting EF Finance (2000): 52-62.

Williamson, John. "Democracy and the "Washington Consensus." World Development 21, 8 (1993): 1329. 1336.

—_. "Privatizing Public Pension Systems: Lessons from Latin America.” Journal of Aging Studies 15, 3 (2001): 285-297.

World Bank. Averting the Old Age Crisis: Policies to Protect the Old and Promote Growth. Oxford: Oxford University Press. (1994). (World Bank 1994)

- World Bank Development Report 2006: Equity and Development. New York: Oxford University Press, 2006. 
Copyright of Journal of Economic Issues is the property of Association for Evolutionary Economics and its content may not be copied or emailed to multiple sites or posted to a listserv without the copyright holder's express written permission. However, users may print, download, or email articles for individual use. 